\title{
María Cañas. Soplar ironía sobre los rescoldos de la historia
}

\author{
Isabel Garnelo Díez \\ Universidad de Málaga \\ isgadiluna@uma.es
}

\author{
Ana María Sedeño Valdellós \\ Universidad de Málaga \\ valdellos@uma.es
}

señala la aparición de una «imaginación melodramática» que tiene que ver con la inclusión de la dimensión afectiva (en sustitución de lo sublime), tan denostada por la alta cultura como el sujeto y la subjetividad lo habían estado por el documental clásico. Podríamos aventurar que esta dimensión afectiva y lúdica surge en el ámbito de las artes visuales con el kitsch como el retorno de lo reprimido. La aparición de la heterogeneidad que hace vacilar la hegemonía de la homogeneidad.

El concepto de "documental melodramático» se combina, en el análisis de la obra de Cañas que realiza Catalá, con la revisión de los procesos seguidos por la autora en la configuración de su obra. En este sentido, Catalá traerá a colación los procedimientos del collage y el fotomontaje, para distinguirlos con precisión histórica del montaje, afirmando que pertenecen a ámbitos estéticos e incluso epistemológicos muy distintos. Sin dejar de señalar el potencial crítico de compromiso político y ético de estos procedimientos en las prácticas ${ }^{\circ}$ artísticas de autores históricos como Hanna Höch, Renau o Heartfield y en la propia Cañas, Catalá insiste en las relaciones que estas estéticas demuestran con los métodos epistemológicos clásicos, argumentando que mientras el cine de ficción se vale de modelos de realidad, el documental -en la vertiente que representa María Cañas-, experimenta sobre la realidad visual. No es casualidad la pieza titulada Meet my meat N.Y. (2008) donde la artista, en lo que parece una entrevista a pie de calle, indaga sobre el american way of life, inquietud que nos remite inevitablemente a la serie de fotomontajes de mismo título del valenciano Josep Renau de 1950-60.

María Cañas nos devuelve la risa sobre nosotros mismos y la historia compartida mediante una lectura irónica 


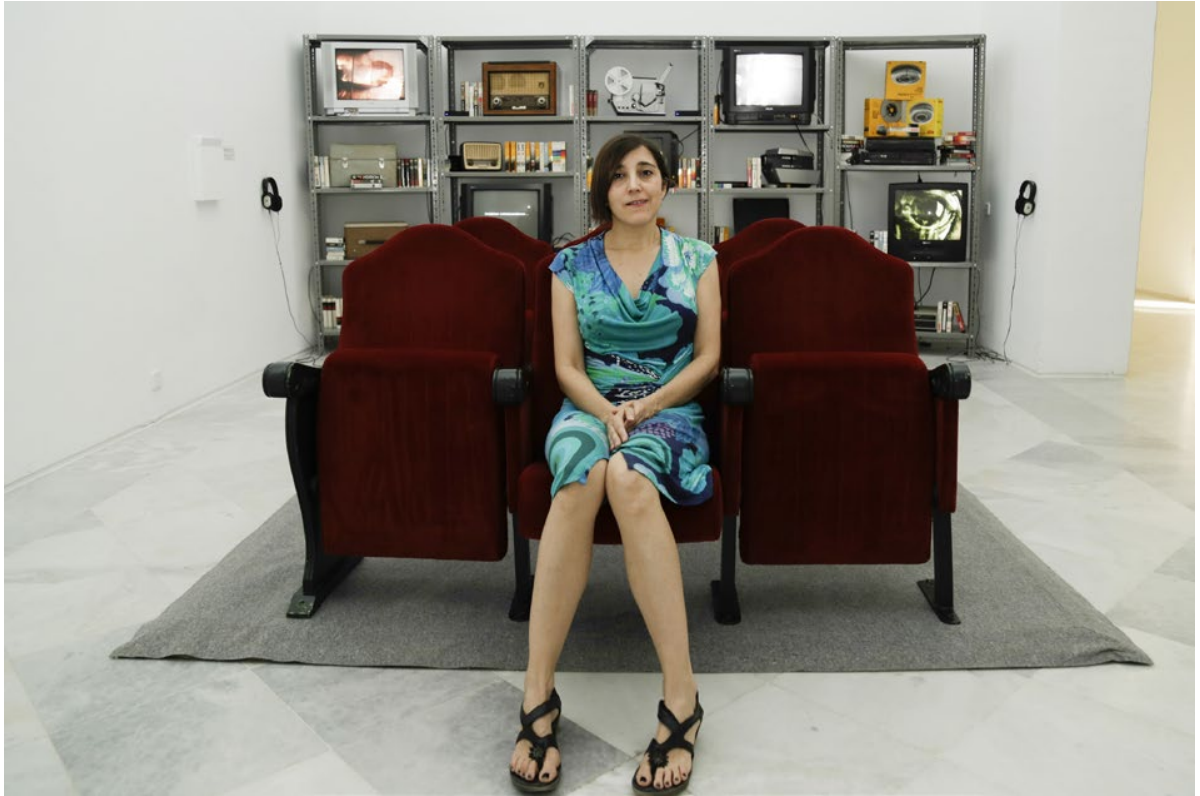

1. María Cañas,

Foto: Ismael Molina, Sevilla Directo, 2016

de las representaciones. Y lo consigue, como señala Catalá, porque incluye la dosis justa de realidad que no impide su retorno siniestro, pero que nos invade con las emociones pertenecientes al contexto original de las imágenes que utiliza. Es un efecto conseguido por la ironía y la mordacidad con la que amalgama sus trabajos, como en Risas en la oscuridad (2015), que tuvimos la oportunidad de ver recientemente en la galería Isabel Hurley de Málaga. En este vídeo, las risas enlatadas, aunque dilatadas, que acompañan a la banda sonora original de los fragmentos de imágenes en collage de películas de Hollywood defienden, como lo expresa la autora,

[...] la carcajada, organizar la rabia y que el humor de todos los colores es una forma de resistencia popular. Mis vídeodelirios se encuentran en el frente de la heterodoxia, del espíritu burlesco-carnavalesco, del esperpento, de la 'risastencia'... fuera de protocolos y en muchas ocasiones se transforman en una provocación a los rituales oficiales (Europa Press 2015).

El trabajo de María Cañas se desvincula de cualquier modelo de representación basado en procedimientos al uso, como podría ser el montaje, y se sirve de los materiales que de forma consensuada podemos considerar como discursos y relatos de lo real, que con naturalidad se organizan y acumulan en el archivo. Estos relatos no son únicamente los que provienen y se legitiman como verdaderos a través del género documental, sino también todo el patrimonio cinematográfico universal del cine de ficción que ha constituido junto al género documental, y lo sigue haciendo, nuestro imaginario común; lo cual no quiere decir que compartamos las narraciones derivadas de estas producciones, al contrario, lo más probable es que estemos en bastante desacuerdo debido, entre otras razones, a los estereotipos que conforman la elaboración de personajes y situaciones. Por no hablar de la ideología que construye su discurso y lo impone como realidad universal. Es aquí precisamente donde inciden muchas de las producciones de María Cañas. Como ella misma sugiere en la presentación de su blog El Animalario: "todo lo que ha quedado registrado en celuloide tiene múltiples posibilidades de remezcla [...] hay muchas versiones de la Historia [...]».

Los procesos que utiliza Cañas en sus vídeos hacen uso de la apropiación, la deconstrucción, la remezla y, en síntesis, trabaja con el found footage. Materiales audiovisuales preexistentes («detritus audiovisual») que la autora disemina para crear dialécticas que pueden resultar imposibles 
2. María Cañas, Foto: Ismael Molina, Sevilla Directo, 2016

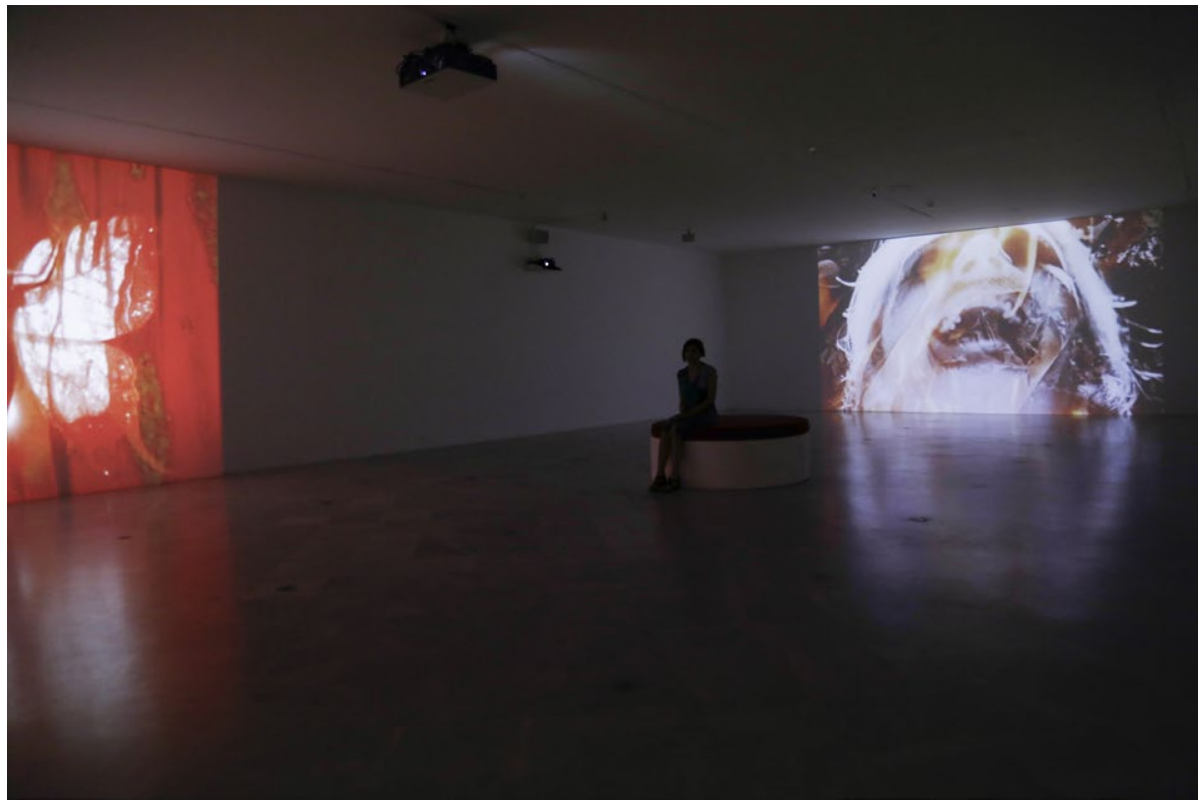

a primera vista, pero que posteriormente se desvelan como un recurso muy potente en su objetivo: «la deconstrucción de la memoria pública y privada, la agitación para la defensa de la idea revolucionaria de una cultura libre, accesible y participativa».

Que «la imagen arde en su contacto con lo real» es la hipótesis de partida del texto del filósofo e historiador del arte Georges Didi-Huberman (2013: 9), el cual plantea la idea del arder de la imagen en relación con el concepto de la imitación que, por sí solo, dejaría al margen toda poética subjetiva entendida como síntoma y como vehículo ineludible para poder hoy orientarnos en la imagen, y ser capaces de dilucidar "qué tipo de conocimiento puede dar lugar la imagen y qué saber sobre la historia puede aportar». También arden en la literalidad de la elipsis las imágenes de Risas en la oscuridad de María Cañas.

En su disertación sobre las imágenes y lo real, Huberman recurre a los trabajos desarrollados por Aby Warburg y Walter Benjamin, cuyas investigaciones sobre las imágenes como fuente de saber han sido paradigma de muchas de las prácticas artísticas contemporáneas. Ambos autores han trabajado con el montaje de imágenes o de textos; ambos tenían la ambición de proponer nuevas lecturas sobre la historia sirviéndose para ello del procedimiento del montaje y de una lectura «a contrapelo» de los textos canónicos mediante la concatenación, en apariencia azarosa, de los objetos seleccionados para sus experimentos. En ambos casos, el punto de partida era también la ausencia de un modelo; su método precisamente consistía en eludir los modelos que la ortodoxia historiográfica y narrativa habían creado para interpretar las producciones culturales y la historia misma. Un reto materializado en dos ejercicios epistemológicos con enormes afinidades como son el Atlas Mnemosyne de Warburg y el Libro de los pasajes de Benjamin. Ambos trabajos, como indica Huberman, se interesan particularmente por la memoria inconsciente, aquella que aparece y se desvela a través del montaje. Propuestas que incluirían sin reservas una invitación a pensar, más que una interpretación o una réplica de lo real.

Trasladada esta tesis a la lectura de la obra de Cañas, para quien la revisión de la memoria nacional es uno de los objetivos de muchas de sus producciones, nos interesaría considerar paralelamente la reflexión que sobre su posición plantea Catalá en el libro citado. Aquí, el autor pone el énfasis en cómo el archivo considerado como memoria histórica y el sujeto como portador de emociones se contraponen en la obra de Cañas para dejar constancia de su propia subjetividad y de esta manera traer a la imagen la mirada del sujeto 
que observa. Precisamente lo que el documental clásico se había preocupado por ocultar. Este hecho deja constancia del «inconsciente técnico» (Didi-Huberman 2013) y su relación directa con la realidad, que no evita que la subjetividad que proyecta el sujeto se filtre en la imagen por mucho distanciamiento que se pretenda, ni puede eludir la confrontación con el devenir de la historia.

Las imágenes arden cuando anulan en su reconfiguración, a través del collage y el fotomontaje, los imaginarios asentados como relatos de lo real. Sin dejar de estar conectados a ese real, por lo que muestran y por las conexiones con las narrativas hegemónicas unidas al contexto histórico del que proceden, no obstante, dan paso a un proceso reflexivo del que nos hacen partícipes y protagonistas. El «canibalismo iconoclasta» de Cañas, como ella misma lo define, se caracteriza por un hambre pantagruélica, por llamar de alguna manera al proceso de acumulación previa y reciclaje posterior al que somete a las imágenes-memoria o al cine de ficción de Hollywood y que pretende, como señala la propia artista: «Hacerle un corte de mangas a Hollywood gracias a la Serie B. La iconoclastia y el reciclaje son para mí un gran placer. Disfruto con el remake y la relectura de la tradición y los tópicos cinematográficos. Padecemos una sobreabundancia de imágenes. La economía de Hollywood produce una inflación tremenda. Por eso, para crear, elegí reciclar, revisitar, reprogramar obras ya existentes, homenajear los recursos de una gran industria y el infinito iconográfico de nuestra sociedad. Ha llegado el momento de filmar lo que nadie filma y donde nadie filma o de hacer cine sin cámaras» (Editorialweb 2010).

La artista ha entendido muy bien que la historia-narración no deja de ser una composición literaria que utiliza los recursos retóricos necesarios para ser memorizada. En cierto sentido, Cañas, como Warburg y Benjamin, utiliza el montaje anacrónico de imágenes, el collage y el fotocollage porque su potencia para poner en acción «temporalidades contradictorias» permite desactivar el rigor de los tópicos que nos construyen y nos congelan en posiciones identitarias o de interpretación de lo real interesadas, para los objetivos de un poder que no deja resquicio desde el que articular su dominio sobre cualquier diferencia o anomalía disidente. Por supuesto, este poder no es una entelequia indefinible, su ubicación está perfectamente clara y habita las instituciones sociales en todos los ámbitos de la vida política y cultural.
Tampoco nosotros somos ajenos a ellas y les damos continuidad haciéndonos eco de sus relatos a través de la educación y la práctica cultural oficial.

Pero también nos llegan en la obra de Cañas los ecos de las otras narrativas que en paralelo han incidido en las fisuras de la historia, constituyéndose como anomalías del sistema. Narrativas con las que nos sentimos más cómodos a la hora de tratar de situar su trabajo en un contexto más amplio, desde las que sin duda habla dirigiendo su relato en una dirección que levanta ampollas precisamente en las posiciones que se sienten perfectamente integradas en los lugares comunes. Nos referimos a los movimientos que a lo largo del siglo XX han dedicado todo su potencial creativo a una práctica de desobediencia nada gratuita; o integrando el "acto gratuito" como táctica reactiva. En este sentido, no podemos dejar de ver las filiaciones de Cañas con el movimiento Dadá y más precisamente con todos los movimientos que, partiendo de sus presupuestos más corrosivos, han puesto sus esfuerzos en el desmantelamiento de las ideologías de cualquier calaña que se pretendían universales y consensuadas. Grupos de guerrilla artística que actuaron en los entornos urbanos desde los años cincuenta y que, al igual que Cañas, se sirvieron de los procedimientos del collage, el fotomontaje y por supuesto del cine y la apropiación. Sirvan como ejemplo los trabajos de grupos como el Movimiento Letrista, la Internacional Situacionista, Fluxus, el Pop o el Punk.

La obra de Cañas es la práctica del video-collage satírico, como ella misma lo define. Y en esta solución entran en juego la mezcla irreverente de imágenes con soluciones de factura precaria que en cierto modo la hermanan con muchas de las piezas de los movimientos citados. La diferencia estriba en que la precariedad de Cañas es intencionada, pues sin duda hoy están al alcance de cualquiera las herramientas necesarias para la elaboración sofisticada de cualquier producto audiovisual.

La imagen precaria, pobre y low cost, donde lo importante es el corte y el empalme, que como señala Hito Steyerl «tiene también que ver con crear cuerpos en el espacio o en el tiempo o en la imaginación: un nuevo cuerpo político, si se quiere» (2015: 26). Y no cabe duda que la Cañas quiere crear ese cuerpo político. Prueba de ello es la elección de las imágenes de entre la marabunta que alberga el archivo digital online del que se sirve. 
Las narraciones de lo nacional son una de las fuentes preferidas por Cañas para mezclar lo popular y lo mítico descrito a través del documental en el archivo, tanto pasado como presente, con el cine de ficción. Esta fusión hace aparecer una «imaginación melodramática» en el sentido que le dan Brooks, Herlinghaus y Martín Barbero (2002: 301), que la entienden no como mera reproducción de fantasías, sino como agencia de su realización, lo que le otorga un carácter performativo. Tendría su rectificación contemporánea en la telenovela y, desde luego, en la dramatización actualizada de los rituales de la liturgia cristiana o el folklore nacional en fiestas como la Semana Santa o la Feria de Sevilla. En el sentido en el que «el melodrama como retórica del exceso permite poner en escena la exaltada imaginación y las emociones del pueblo [...] ayudando a producir sentido en medio de las experiencias cotidianas de individuos y grupos sociales diversos» (Herlinghaus, 2002). Desde esta perspectiva parece muy acertada la filiación que Catalá establece entre el melodrama y la obra de Cañas. Podemos ver un reflejo de este planteamiento en obras como Sè Villana. La Sevilla del Diablo (2013), de la que la autora dice la autora que es un muestrario de la industria de los fanatismos, un homenaje a «la historia aperreá, a las prostitutas, al folklore de pueblo, no como colección de antiguallas sino como intrahistoria a través de la resistencia fuera de protocolos y en muchas ocasiones transformadas en una provocación a los rituales oficiales» (Romero 2015). O en Holy Thriller (2011), vídeocreación en la que se intercalan imágenes documentales sobre la Semana Santa y donde el sonido nos hace ver a los costaleros moviéndose al ritmo del Bille Jean de Michael Jackson, interpretada por una banda de cornetas y tambores como las que acompañan al cortejo procesional en estas fiestas. "Me duele España como a Miguel de Unamuno», señala Cañas con cinismo (Gascó 2013). Sin duda una política de la cita subversiva, un ejercicio de Détournement en su más amplio sentido, poniendo en imagen relatos descabellados que subvierten el mundo del buen gusto y las reglas establecidas. El trabajo de Cañas se corresponde con una imaginación obsesiva, no en vano la llaman ciberdiógenes, que propone lecturas alternativas a las que podríamos esperar del archivo. Podríamos decir que su trabajo sopla ironía sobre el archivo documental, esos rescoldos de la historia, para hacerlos arder de nuevo con sus narraciones incendiarias.

\section{Bibliografía}

CATALÁ, Josep M. (2009), «El documental melodramático de María Cañas. Ética y estética del collage», Piedra, papel y tijera. El collage en el cine documental, Ocho y Medio, Libros de Cine, Madrid.

DIDI-HUBERMAN, G. (2013), Cuando las imágenes tocan lo real, Círculo de Bellas Artes, Madrid.

EDITORIALWEB (2010), Blog del [S8] de la 7. ${ }^{a}$ Mostra de Cinema Periférico, "Cómo ser María Cañas o una homo videns compulsiva", 27/05/2010. En: http://www.s8cinema.com/portal/2010/05/27/como-ser-maria-canas-o-una-homo-videns-compulsiva/ (consultado el 09/05/2016).

EUROPA PRESS, 17/06/2015, «Archivera de Sevilla. «María Cañas presenta en el CAAC su exposición "Risas en la oscuridad”. En: <http://www. europapress.es/andalucia/cultura-00621/noticia-cultura-maria-canas-presenta-caac-exposicion-risas-oscuridad-20150617195251. html> (consultado el 02/05/2016).

GASCÓ, Gabriel (2013), Diagonal, «El audiovisual hecho con tres duros y mucha pasión está sanísimo», 14/11/2013. En: <https://www.diagonalperiodico.net/andalucia/20732-audiovisual-hecho-con-tres-duros-y-mucha-pasion-esta-sanisimo.html> (consultado el 10/05/2016).

MARTíN BARBERO, J. (2002), «La telenovela desde el reconocimiento a la anacronía», en HERLINGHAUS, Herman (ed.), Narraciones anacrónicas de la modernidad: melodrama e intermedialidad en América Latina, Editorial Cuarto Propio, Chile.

ROMERO, Jaime (2016), «Sobre cornadas visuales y saltos de derechos de autor a la torera. Entrevista a María Cañas», 25/06/ 2015 Parabelum 1 <http://parabelum.es/cornadas-visuales-y-me-salto-los-derechos-de-autor-a-la-torera/> (consultado el 09/05/2016).

STEYERL, H. (2015), «El arte, un lugar de ensayo», Hito Steyerl en conversación con João Fernandes, en Duty-Free Art, Museo Nacional Centro de Arte Reina Sofía, Madrid. 